\title{
The HrpX Protein Activates Synthesis of the RaxX Sulfopeptide, Required for Activation of XA21-Mediated Immunity to Xanthomonas oryzae pv. oryzae
}

\author{
Anna Joe, ${ }^{1}$ Valley Stewart, ${ }^{2}$ and Pamela C. Ronald ${ }^{1,3, \dagger}$ \\ ${ }^{1}$ Department of Plant Pathology, University of California, Davis, CA 95616, U.S.A. \\ ${ }^{2}$ Department of Microbiology \& Molecular Genetics, University of California, Davis, CA 95616, U.S.A. \\ ${ }^{3}$ Genome Center, University of California, Davis, CA 95616, U.S.A.
}

Accepted 6 August 2021.

\begin{abstract}
Upon encountering a susceptible plant host, a bacterial pathogen expresses specific virulence factors. For example, in planta, the Xanthomonas HrpX protein activates transcription of roughly 150 genes encoding components of the type III secretion system or its translocated effectors, as well as other secreted proteins implicated in pathogenesis. Here, we show that $X$. oryzae pv. oryzae growth in planta or in HrpXinducing XOM2 media resulted in HrpX-dependent transcription of the $\operatorname{rax} X$ and $\operatorname{raxST}$ genes that control production of the RaxX sulfopeptide, exported through a type I secretion system. The RaxX protein is required for activation of XA21mediated immunity in $\mathrm{Xa}^{+} 1^{+}$rice lines. We identified potential plant-inducible promoter elements upstream of the likely $5^{\prime}$ ends of the $\operatorname{raxX}$ and $\operatorname{raxST}$ transcripts. Deletions and nucleotide substitutions confirmed that these elements are required for HrpX-dependent expression of $\operatorname{raxX}$ and $\operatorname{raxST}$. We conclude that $\operatorname{raxX}$-raxST gene expression is induced by HrpX during growth in planta and, therefore, is coordinately expressed with other genes required for pathogenesis.
\end{abstract}

Keywords: HrpX, plant-inducible promoter, XA21-mediated immunity, Xanthomonas oryzae pv. oryzae

Many free-living bacteria can colonize and cause disease in a susceptible host. Adaptation to this changed ecological niche requires substantial transcriptional reprogramming. Genes whose products participate in a shared context such as pathogenicity usually are controlled by one or more environmentally responsive transcription regulators (Leonard et al. 2017; Wang and Qian 2019). This global regulation ensures that the appropriate gene set is expressed under appropriate circumstances.

${ }^{\dagger}$ Corresponding author: P. C. Ronald; pcronald@ucdavis.edu

Current address for Anna Joe: Zentrum für Molekularbiologie der Pflanzen (ZMBP), Eberhard Karls Universität, Tübingen, Germany.

Funding: National Institute of General Medical Sciences, grant number GM122968.

*The $\boldsymbol{e}$-Xtra logo stands for "electronic extra" and indicates that supplementary materials are published online.

The author(s) declare no conflict of interest.

(c) (1) () () Copyright $\odot 2021$ The Author(s). This is an open access article distributed under the CC BY-NC-ND 4.0 International license.
The $\gamma$-proteobacterium Xanthomonas oryzae pv. oryzae causes bacterial blight disease, a vascular infection of rice crops in Asia and Africa (Niño-Liu et al. 2006). X. oryzae pv. oryzae secretes a sulfopeptide named $\operatorname{Rax} X$ (required for activation of XA21-mediated immunity $\mathrm{X}$ ) that is highly similar to the plant PSY sulfopeptide hormone (Pruitt et al. 2017). Rice lines carrying the XA21 immune receptor are able to mount an effective defense response to $X$. oryzae pv. oryzae strains that synthesize the RaxX sulfopeptide (Song et al. 1995). Although RaxX is synthesized by several Xanthomonas spp. and pathovars, XA21 recognizes only the variant made in the majority of $X$. oryzae pv. oryzae strains (Liu et al. 2019; Pruitt et al. 2015).

RaxX synthesis is directed by the $\operatorname{raxX}$-raxSTAB gene cluster (da Silva et al. 2004; Pruitt et al. 2015) (Fig. 1A) encoding the RaxST tyrosyl-protein sulfotransferase as well as the Raxspecific type I secretion system (T1SS) components: RaxB, the peptidase-containing ATP-binding cassette transporter; and RaxA, the periplasmic adaptor protein. These proteins posttranslationally modify the 60-residue RaxX precursor by sulfation and endoproteolytic cleavage and secrete the mature sulfopeptide into the extracellular space (Han et al. 2012; Luu et al. 2019). Despite the importance of the RaxX biosynthetic pathway in the interaction of $X$. oryzae pv. oryzae with its host, the regulatory factors that control $\operatorname{rax} X$-rax $S T A B$ gene expression have not yet been identified.

Xanthomonas spp. display hypersensitive reaction and pathogenicity (Hrp) phenotypes, inducing a hypersensitive reaction on incompatible plants and disease symptoms on compatible plants upon infection (Lindgren 1997). These phenotypes depend upon two sets of $\geq 20$ genes each. The first set, collectively termed hrp genes (Bogdanove et al. 1996), encodes a type III secretion system (T3SS) that translocates bacterial effector proteins into the host cytoplasm (Tampakaki et al. 2010; Wagner et al. 2018). The second set, collectively termed Xanthomonas outer protein (xоp) genes (White et al. 2009), encodes the T3SS-secreted effector proteins that disrupt numerous aspects of host cell function and signaling (Büttner 2016). The hrp and xop gene expression is induced in planta (Schulte and Bonas 1992) and, for $X$. oryzae pv. oryzae, in the xylose-containing XOM2-defined medium (Tsuge et al. 2002). This plant-inducible expression requires the HrpX DNA-binding transcription activator (Kamdar et al. 1993; Wengelnik and Bonas 1996). In most cases, HrpXdependent transcription requires a plant-inducible promoter (PIP) box sequence, which forms the transcription factor regulatory site for binding HrpX (Cunnac et al. 2004; Fenselau and Bonas 1995; Furutani et al. 2006; Koebnik et al. 2006; Mukaihara et al. 2004; Noël et al. 2002; Oku et al. 2004; Tsuge 
et al. 2005). HrpX synthesis is governed by a complex regulatory network that converges on the response regulator $\mathrm{HrpG}$, which activates $h r p X$ transcription (Büttner and Bonas 2010; Teper et al. 2021; Tsuge et al. 2014). Thus, the HrpX protein directly activates $h r p$ and xop gene transcription initiation.

HrpX-dependent activation also regulates a diverse array of other virulence factors and, therefore, is a global regulator for a broad pathogenicity regulon (Büttner and Bonas 2010; Teper et al. 2021; Zheng et al. 2021). Here, we report that X. oryzae pv. oryzae $\operatorname{raxX}$ and $\operatorname{rax} S T$ transcription both are activated by HrpX during growth in planta and in XOM2 medium, and we identify the PIP box promoter sequence for each gene. These findings expand knowledge on genes regulated by HrpX, and support the hypothesis that RaxX is a virulence factor (Pruitt et al. 2017).

\section{RESULTS}

$\operatorname{rax} X$ and $\operatorname{raxST}$ induced gene expression requires $h r p X^{+}$.

We grew cultures of $X$. oryzae pv. oryzae strain $\mathrm{PXO} 99^{\mathrm{A}}$ in peptone-sucrose broth (PSB) complex medium and XOM2 defined medium, and also isolated bacteria from infected rice. As measured by quantitative reverse-transcription (qRT)-PCR, both $\operatorname{raxX}$ and $\operatorname{raxST}$ gene expression was strongly induced during growth in XOM2 or rice (Fig. $2 \mathrm{~A}$ and $\mathrm{B}$ ). Based on this result, we hypothesized that $\operatorname{HrpX}$ is required for $\operatorname{raxX}$ and $\operatorname{rax} \mathrm{ST}$ expression during growth in XOM2 medium.

To test this hypothesis, we interrupted the $X$. oryzae pv. oryzae $h r p X$ coding sequence with a conditionally replicating plasmid to create a null allele, $h r p X:: \Omega$. Inoculation results indicated that the $h r p X:: \Omega$ strain is nonpathogenic on rice, in accordance with prior studies (Kamdar et al. 1993) (Supplementary Fig. S1). After complementing the $h r p X:: \Omega$ lesion with a plasmid carrying the $h r p X^{+}$allele, we grew $X$. oryzae pv. oryzae $h r p X^{+}$, $h r p X:: \Omega$, and $h r p X:: \Omega / h r p X^{+}$complemented strains in PSB, $\mathrm{XOM} 2$, or rice. Both $\operatorname{rax} X$ and $\operatorname{raxST}$ gene expression was fully dependent upon the $h r p X^{+}$allele (Fig. 3). These results indicate that $\operatorname{rax} X$-rax $S T A B$ gene cluster transcription is activated by the HrpX protein.

Other T1SS-related genes are HrpX independent.

The $\operatorname{raxC}$ gene encodes the ortholog of TolC, the outer membrane channel shared by T1SS and related secretion systems, which is required for RaxX secretion (da Silva et al. 2004; Luu et al. 2019). The pctB gene encodes the peptidase-containing ATP-binding cassette transporter subunit for the PctAB T1SS in $X$. oryzae $\mathrm{pv}$. oryzae, which can partially substitute for the RaxAB T1SS (Luu et al. 2019). In contrast to the $\operatorname{raxX}$ and $\operatorname{rax} S T$ genes, $\operatorname{rax} C$ and $p c t B$ gene expression was essentially

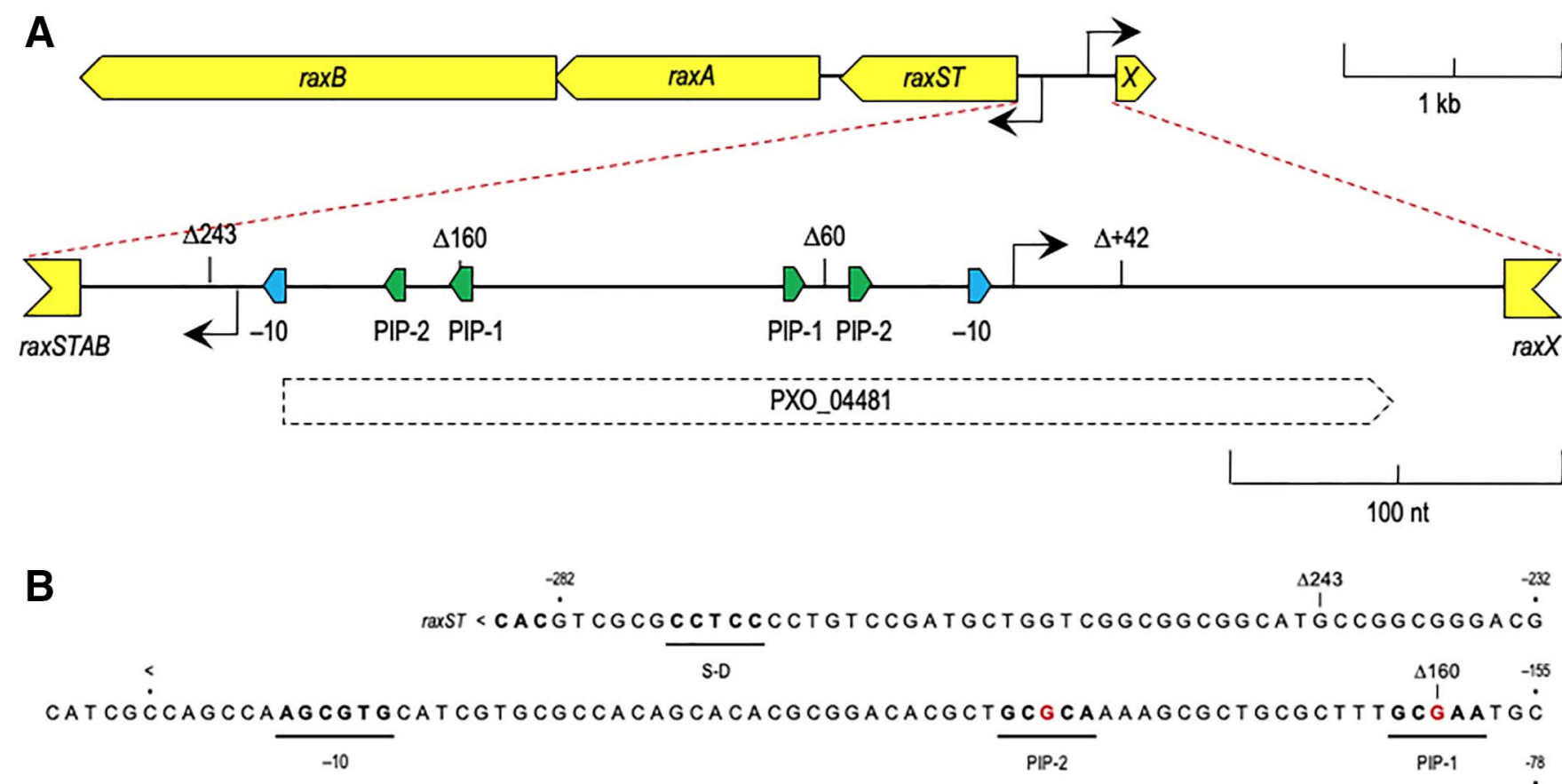

CGGCGATCCGGCTGAGCGGTCGGCAGCGCTTGCAGTGACCGGCATCACATCGCCGTGCACCGGCACGGACCTGGCGG

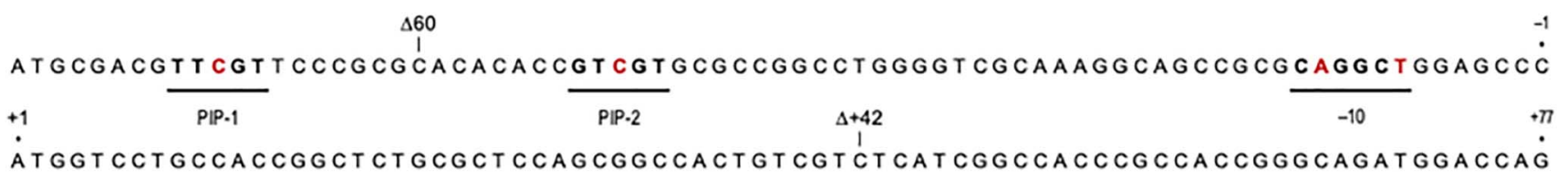

$+148$

ACGATCACGCCGCCGTCCCTTCAGGCGCTGTGACGGTGCGTAAGAAGGGCACAACCTGCGAGGACGTCAGAATG> PaXX

Fig. 1. The $\operatorname{rax} X$-raxSTAB divergent transcription control region. A, The $\operatorname{rax} X$-raxSTAB gene cluster includes the 431-bp control region (inset) between the $\operatorname{rax} S T$ and $\operatorname{raxX}$ initiation codons. Relative locations are shown for the -10 box sequences (blue), plant-inducible promoter (PIP) box sequences (green), deletion endpoints $(\Delta)$, and predicted transcription initiation sites (arrows). The putative PXO_04481 coding region is shown as a dashed arrow. Drawn to scale. B, Sequence is from the $\operatorname{raxST}$ initiation codon through the $\operatorname{rax} X$ initiation codon. Position +1 is the $\operatorname{rax} X$ transcription initiation site deduced from 5'-rapid amplification of cDNA ends analysis (see text). Shine-Dalgarno (S-D), -10 box, and PIP box sequences are indicated. 
unchanged regardless of the culture medium (Fig. 2). These results indicate that HrpX does not regulate T1SS-related gene expression broadly.

\section{Identification of a PIP box promoter sequence required} for $\operatorname{rax} X$ induced gene expression.

The PIP consensus sequence comprises repeated pentanucleotides, termed the PIP-1 and PIP-2 half-sites, with 15-nucleotide (nt) spacing (TTCGB-N15-TTCGB, where $\mathrm{B}=\mathrm{A}, \mathrm{C}$ or $\mathrm{T}$ ) (Cunnac et al. 2004; Koebnik et al. 2006) (Supplementary Fig. S2). A -10 sequence with consensus YANNRT (where $\mathrm{Y}=\mathrm{C}$ or $\mathrm{T}$ and $\mathrm{R}=\mathrm{A}$ or $\mathrm{G}$ ), spaced $31 \pm 1$ nt downstream of the PIP2 half-site, directs RNA polymerase to the transcription initiation point (Cunnac et al. 2004; Mejía-Almonte et al. 2020; Tsuge et al. 2005).
We performed two experiments to locate the $\operatorname{rax} X$ promoter. First, we used 5'-rapid amplification of cDNA ends (RACE) to identify potential transcript $5^{\prime}$ ends. We designated the most $5^{\prime}$ of these ends as the probable transcription initiation site (Fig. 1B, position +1). Second, we deleted varying segments of the sequence upstream of the $\operatorname{raxX}$ gene (Fig. 1B). Deletions to positions -243 and -160 had no effect on $\operatorname{raxX}$ gene expression during growth in HrpX induction conditions (Fig. 4). In contrast, deletions to positions -60 and +42 each abolished expression (Fig. 4).

These results together identified the predicted PIP box promoter sequence, which extends upstream of position -60 (Fig. 1B). A match to the consensus -10 element of PIP box promoters is positioned optimally ( $7 \mathrm{nt}$ ) upstream of the identified transcription initiation site +1 (Busby and Ebright 1994) (Fig. 1B). This $\operatorname{raxX}$ PIP box promoter sequence is conserved in
A $\operatorname{rax} X$

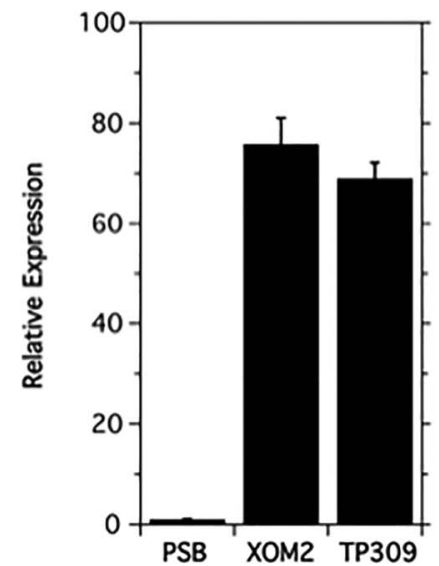

B $\operatorname{raxST}$

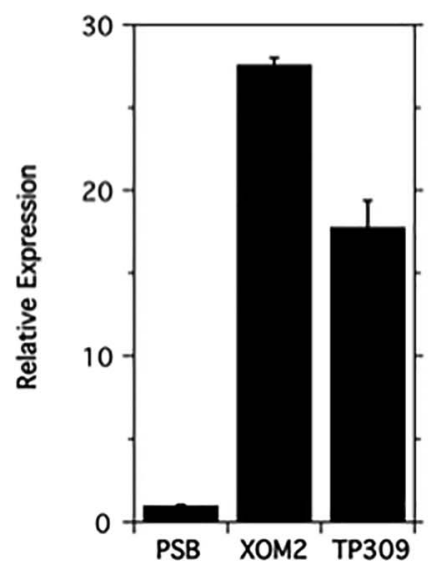

C $\operatorname{raxC}$

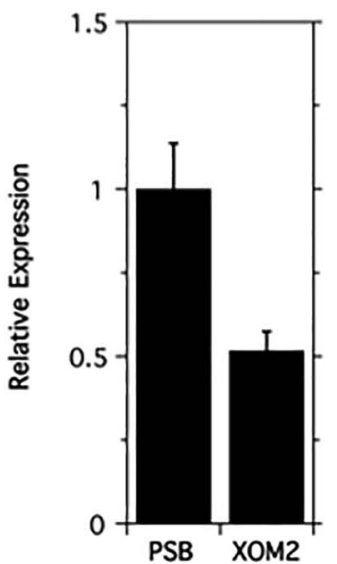

D pctB

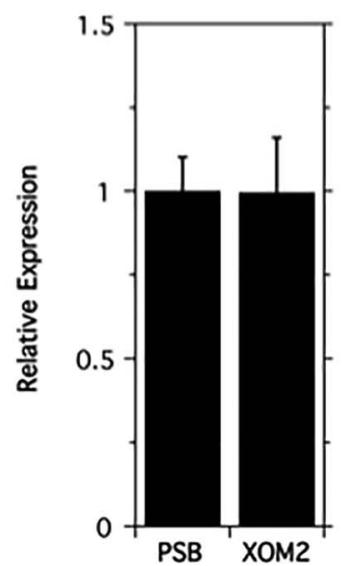

Fig. 2. Expression from the $\operatorname{rax} X$ and $\operatorname{raxST}$ promoters is plant inducible. RNA was extracted from PXO99 ${ }^{\mathrm{A}}$ strains cultured in peptone-sucrose broth (PSB) or XOM2 media for $8 \mathrm{~h}$ or in TP309 plants with leaf samples collected 8 days after inoculation. A, $\operatorname{raxX}$; $\mathbf{B}, \operatorname{raxST}$; C, $\operatorname{raxC}$; and $\mathbf{D}, \operatorname{pctB}$ gene expression was analyzed by quantitative reverse-transcription PCR, normalized to expression from the ampC2 (PXO_RS14730) reference gene, and expressed as fold change relative to the PSB-cultured samples. Bars depict average expression level \pm standard deviation of three technical replicates. Similar results were observed in two independent experiments.

\section{A $\operatorname{rax} X$}

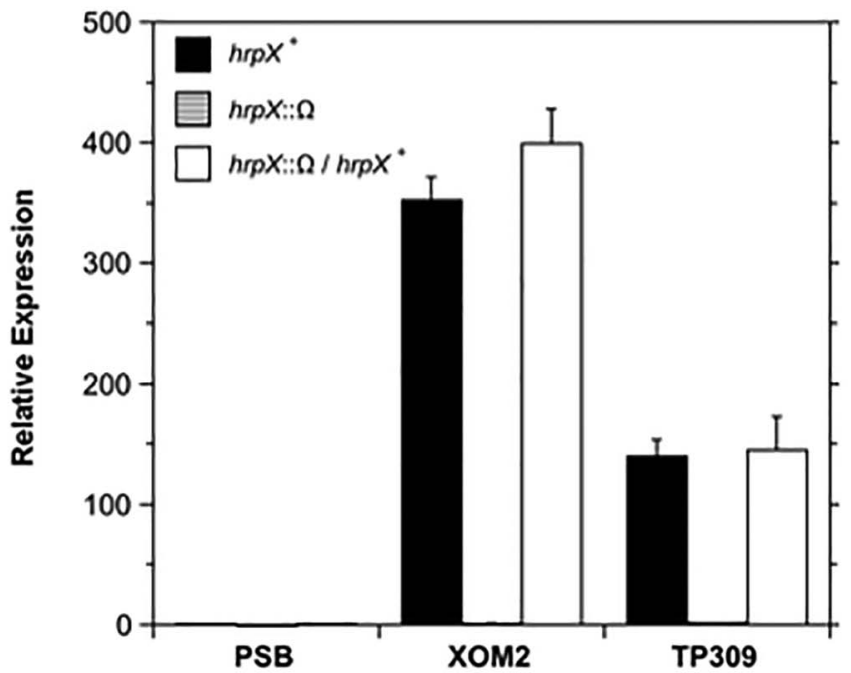

\section{B $\operatorname{rax} S T$}

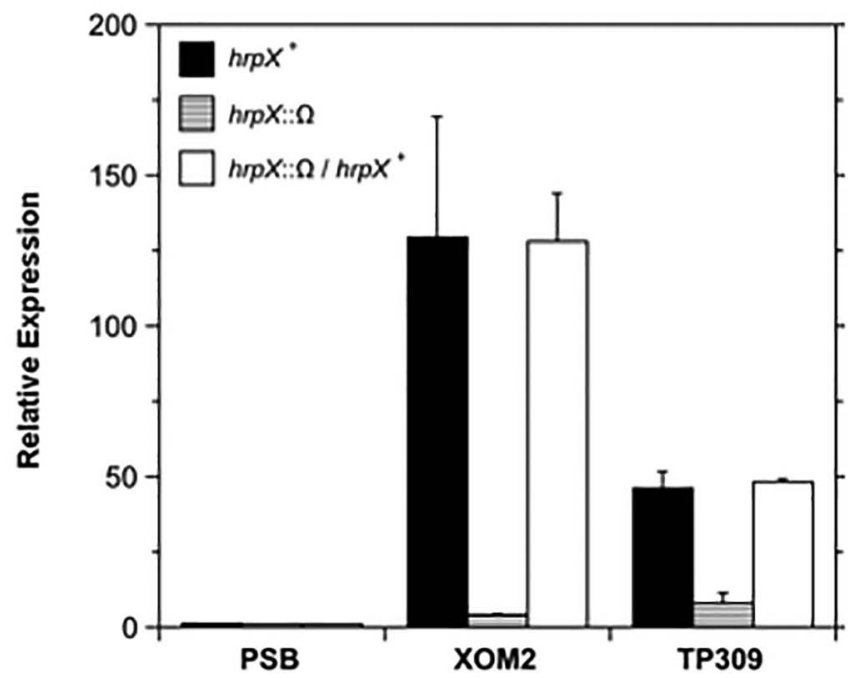

Fig. 3. $\operatorname{rax} X$ and $\operatorname{raxST}$ transcription requires $h r p X^{+}$. RNA was extracted from the $h r p X^{+}$strain and from $h r p X:: \Omega$ strains with or without the phrpX plasmid. Strains were grown in peptone-sucrose broth (PSB) and XOM2 media for $8 \mathrm{~h}$ or in TP309 plants with leaf samples collected 12 days after inoculation. A, $\operatorname{raxX}$ and $\mathbf{B}, \operatorname{raxST}$ gene expression was analyzed by quantitative reverse-transcription PCR, normalized to expression from the ampC2 (PXO_RS14730) reference gene, and expressed as fold change relative to the PSB-cultured samples. Bars depict average expression level \pm standard deviation of three technical replicates. Similar results were observed in three independent experiments. 
other Xanthomonas spp. carrying the $\operatorname{rax} X$ gene $\left(\operatorname{Rax}^{+}\right)$(Fig. 5A), as expected for a functional regulatory element (Buvinger and Riley 1985). The PIP-1 half-site matches the consensus (TTCGT) whereas the PIP-2 half-site has one mismatch (GTCGT). However, a mutant $h r c U$ PIP-1 half-site with G substituted for T at position 1 retains approximately one-fifth of wild-type activity (Tsuge et al. 2005; Tsuge et al. 2014). The -10 sequence also matches the consensus except at position 5 (CAGGCT), which apparently is not conserved in X. oryzae pv. oryzae strain PXO99 ${ }^{\mathrm{A}}$ PIP box promoters (Supplementary Fig. S2).

To test the functionality of these sequences, we used sitespecific mutagenesis to convert the invariant $\mathrm{C}$ at position 3 to A individually in each PIP box half-site (Figs. 1B, 5A, and 6A). This $\mathrm{C}$ residue is essential for PIP box promoter function (Koebnik et al. 2006; Tsuge et al. 2005, 2014). Indeed, both of the C-to-A changes individually substantially reduced $\operatorname{raxX}$

\section{A Deletions}
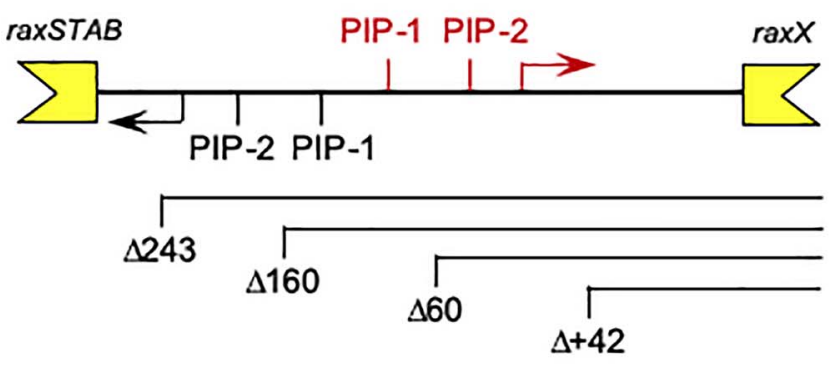

B $\operatorname{rax} X$

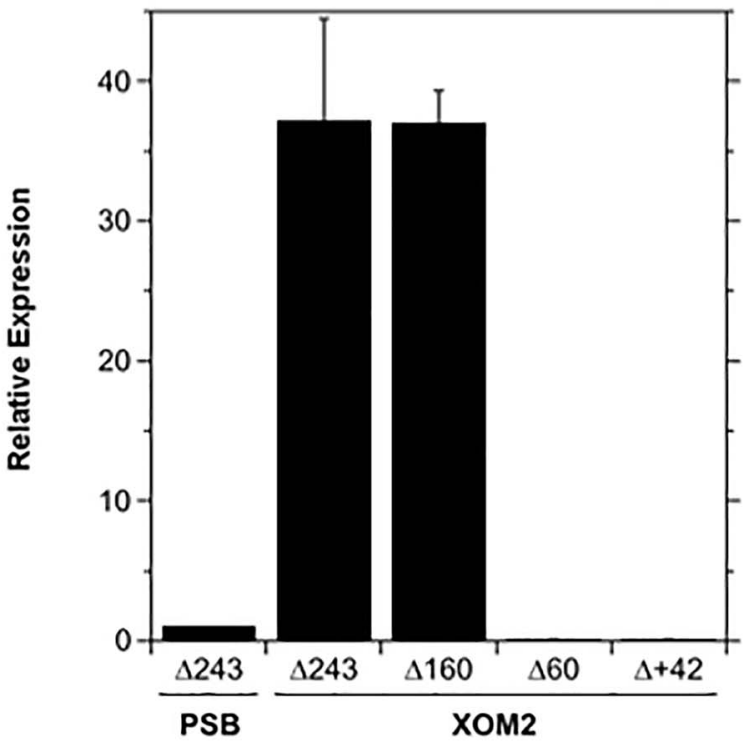

Fig. 4. 5' Deletions help delimit the $\operatorname{rax} X$ promoter. A, Schematic of the raxST-raxX intergenic region showing the extent of the tested deletions. Locations of plant-inducible promoter (PIP) box sequences are shown for $\operatorname{raxX}$ (red) and $\operatorname{raxST}$ (black). $\operatorname{raxX}$ and predicted $\operatorname{raxST}$ transcription initiation sites are indicated by the rightward (red) and leftward (black) arrows, respectively. The $\operatorname{rax} X$ control region in plasmid praxX $\Delta 243$ was further truncated to obtain the deletions $\Delta 160, \Delta 60$, and $\Delta+42 . \mathbf{B}$, Results for $\Delta \operatorname{rax} X$ strains carrying the indicated plasmids. Strains were grown in peptone-sucrose broth (PSB) or XOM2 media for 8 h. $\operatorname{raxX}$ gene expression was analyzed by quantitative reverse-transcription PCR, normalized to expression from the ampC2 (PXO_RS14730) reference gene, and expressed as fold change relative to the PSB-cultured samples. Bars depict average expression level \pm standard deviation of three technical replicates. Similar results were observed in two independent experiments. expression during growth in XOM2 medium (Fig. 6A). We also made dual substitutions at conserved positions 2 (A-to-C) and 6 (T-to-G) in the predicted -10 region (Fig. 1B, Figure 5A, Figure $6 \mathrm{~A})$. These changes similarly reduced $\operatorname{rax} X$ gene expression during growth in XOM2 medium (Fig. 6A). These results indicate that the predicted PIP box promoter is essential for $\operatorname{raxX}$ gene expression during growth in $\mathrm{HrpX}$ induction conditions.

Identification of a PIP box promoter sequence required for $\operatorname{rax} S T$ induced gene expression.

A predicted PIP box promoter is positioned to initiate transcription approximately $57 \mathrm{nt}$ upstream of the $\operatorname{raxST}$ GTG initiation codon (Fig. 1B). This $\operatorname{raxST}$ PIP box promoter sequence is conserved in $\mathrm{Rax}^{+}$Xanthomonas spp. (Fig. 5B). The PIP-1 half-site matches the consensus (TTCGC) whereas the PIP-2 half-site has one mismatch (TGCGC). A mutant $h r c U$ PIP-1 half-site with $\mathrm{G}$ substituted for $\mathrm{T}$ at position 2 (Fig. 5) retains approximately one-third of wild-type activity (Tsuge et al. 2005, 2014). The -10 sequence also matches the consensus except at position 5 (CACGCT).

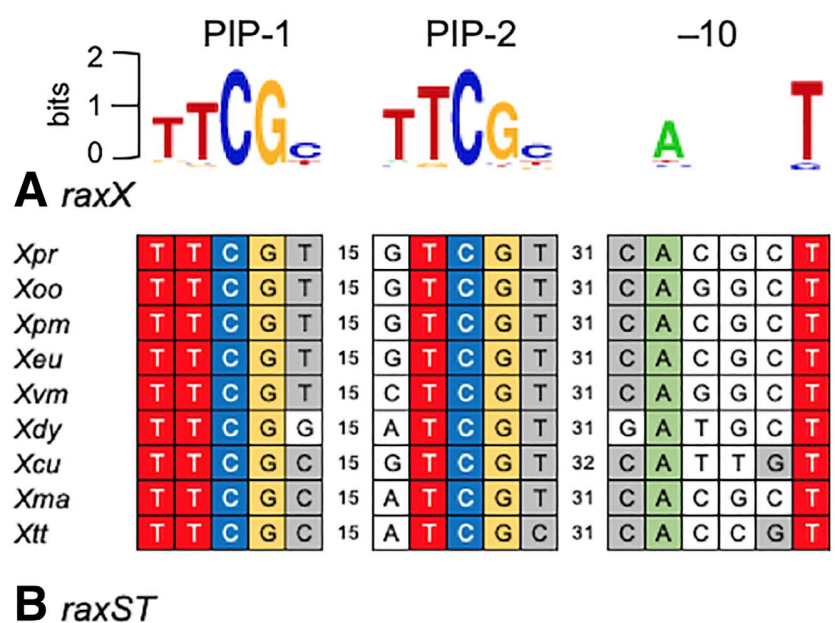

Fig. 5. $\operatorname{raxX}$ and $\operatorname{raxST}$ plant-inducible promoter (PIP) box promoter sequences are conserved. PIP box promoter sequences are shown for $\mathbf{A}$, $\operatorname{raxX}$ and $\mathbf{B}, \operatorname{raxST}$. The sequence logo is derived from 47 Xanthomonas oryzae pv. oryzae strain PXO99 ${ }^{\mathrm{A}} \mathrm{HrpX}$-dependent promoters (Supplementary Fig. S2). The published consensus (Cunnac et al. 2004; Koebnik et al. 2006), and substitutions tested for effects on HrpX-dependent expression are indicated at the bottom. Abbreviations and accession numbers: $X p r=$ $X$. prunicola CFBP 8353 (NZ_PHKV01000003.1), Xoo $=X$. oryzae pv. oryzae PXO99 ${ }^{\mathrm{A}}\left(\mathrm{NC} \_010717.2\right), X p m=X$. phaseoli $\mathrm{pv}$. manihotis UA536 $(\mathrm{NZ}$ _AKEQ01000107.1), Хеu $=X$. euvesicatoria 85-10 (NC_007508.1), $X v m=X$. vasicola $\mathrm{pv}$. musacearum NCPPB 4392 (NZ_AKBI01000007.1), $X d y=X$. dyei CFBP 7245 (NZ_MDEE01000001.1), Xcu $=$ X. cucurbitae CFBP 2542 (NZ_MDED01000003.1), Xma $=X$. maliensis M97 (NZ_AQPR01001212.1), and Xtt $=X$. translucens pv. translucens DAR61454 (NZ_KB316632.1). 
As done for the $\operatorname{rax} X$ promoter described above, we used sitespecific mutagenesis to convert the invariant $\mathrm{C}$ at position 3 to A individually in each PIP box half-site (Figs. 1B, 5B, and 6B). Again, both of these changes substantially reduced $\operatorname{rax} S T$ gene expression during growth in XOM2 medium (Fig. 6B). These results indicate that the predicted PIP box promoter is essential for $\operatorname{raxST}$ gene expression during growth in $\mathrm{HrpX}$ induction conditions.

\section{PIP box promoter sequences}

in $X$. oryzae pv. oryzae strain PXO99 ${ }^{\mathrm{A}}$.

Several prior studies have compiled lists of HrpX-activated genes and analyzed their regulatory regions for PIP box half-site and -10 sequences (Furutani et al. 2006; Koebnik et al. 2006; Song and Yang 2010; Tsuge et al. 2014; Wang et al. 2008; Yamazaki et al. 2008). To provide a genome-wide census of potential HrpX-activated genes, we examined recent RNA sequencing (RNA-seq) data that include comparisons between wild-type and $\Delta h r p X$ null strains cultured in XOM2 medium (Zheng et al. 2021), as described in Materials and Methods (Supplementary Fig. S3). Although some predicted products have unknown function beyond "conserved hypothetical," others are categorized generally as involved in metabolic substrate catalysis or transport.

We generated a sequence logo (Crooks et al. 2004; Schneider and Stephens 1990) from the resulting collection of 47 HrpX-dependent promoters in X. oryzae pv. oryzae strain PXO99 $^{\mathrm{A}}$ (Fig. 5; Supplementary Fig. S2). The results are entirely consistent with prior analyses, with the exception that the -10 region sequences are conserved only at positions 2 and 6 (Fig. 5; Supplementary Fig. S2). Positions 2 and 6 are the most critical for promoter activity and, generally, promoters subject to positive regulation do not conform closely to the consensus sequence (Busby and Ebright 1994; Lee et al. 2012; Shultzaberger et al. 2007).

\section{DISCUSSION}

The HrpX pathogenicity regulon includes $>100$ genes, expressed during growth in planta, most of whose functions are essential for or contribute to Xanthomonas virulence (Büttner and Bonas 2010; Teper et al. 2021; Tsuge et al. 2014). Most of these genes encode components of the complex T3SS and the numerous T3SS-secreted effectors. Nevertheless, HrpX also activates gene expression for some type II secretion system (T2SS)secreted proteases and hydrolases (Furutani et al. 2004; Wang et al. 2008; Yamazaki et al. 2008). Here, we show that genes for a T1SS-secreted substrate $(\operatorname{rax} X)$ and its modifying enzyme $(\operatorname{raxST})$ also are part of the HrpX pathogenicity regulon. These results support the hypothesis that the RaxX sulfopeptide functions as a virulence factor (Pruitt et al. 2017).

Recently, Zheng et al. (2021) published RNA-seq data that identifies approximately 150 genes whose expression depends on $h r p X^{+}$. These data identify virtually all known HrpG- and HrpX-dependent genes, including hrp and xop genes. These data also identify all four genes in the $\operatorname{raxX} \mathrm{x} \operatorname{rax} S T A B$ cluster as dependent upon HrpX for expression (Supplementary Fig. S3). These results independently corroborate the results reported in this article and show additionally that $\operatorname{rax} A B$ gene expression is HrpX dependent, as expected for the predicted $\operatorname{rax} S T A B$ operon (Fig. 1A).

The PIP-2 half-sites for both the $\operatorname{raxST}$ and the $\operatorname{raxX}$ promoters do not conform exactly to the consensus (Fig. 5). However, mutational analysis shows that these substitutions reduce but do not eliminate activity from the model HrpX-dependent

\section{A $\operatorname{rax} X$}
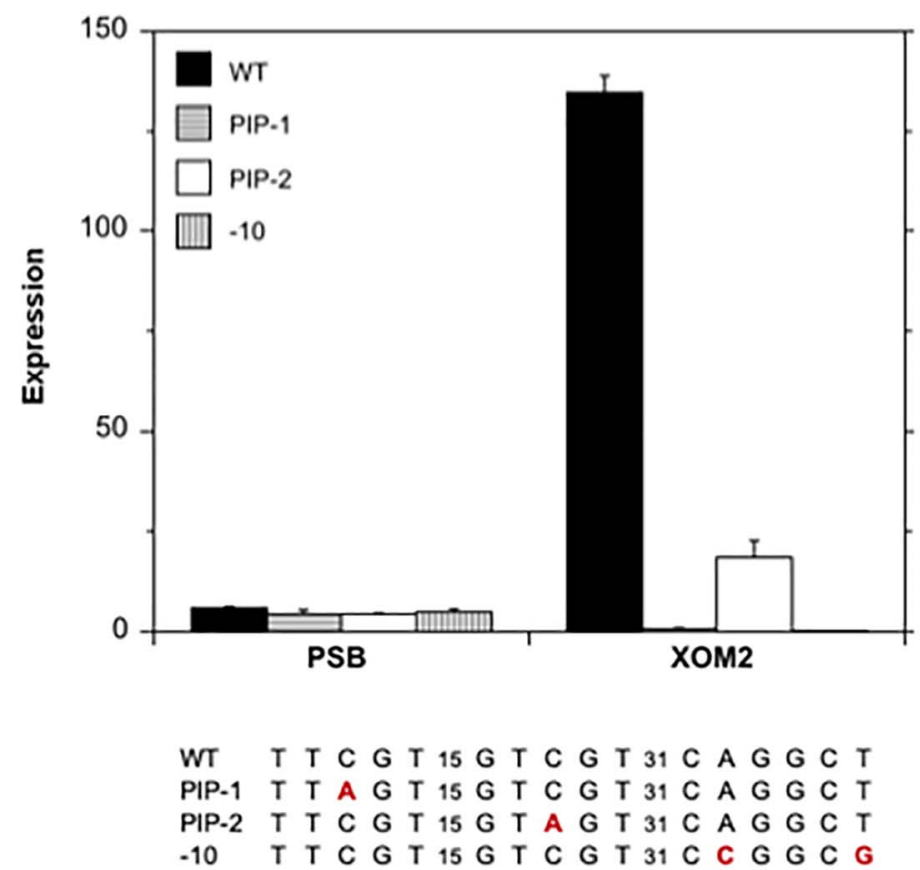

\section{B $\operatorname{raxST}$}

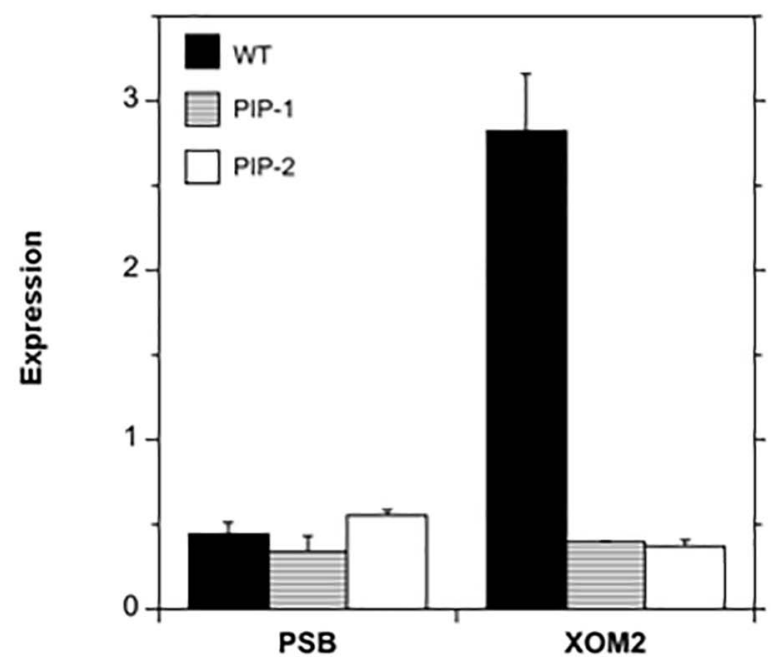

$\begin{array}{llllllllllll}W T & T & T & C & G & C & 15 & T & G & C & G & C \\ \text { PIP-1 } & T & T & A & G & C & 15 & T & G & C & G & C \\ \text { PIP-2 } & T & T & C & G & C & 15 & T & G & A & G & C\end{array}$

Fig. 6. Plant-inducible promoter (PIP) box promoter substitutions reduce $\operatorname{rax} X$ and $\operatorname{rax} S T$ gene expression. A, Results for $\Delta$ raxX mutant strains carrying derivatives of plasmid praxX $\Delta 160$ with the indicated nucleotide substitutions in the PIP-1, PIP-2, or -10 elements. B, Results for $\Delta$ raxST mutant strains carrying derivatives of plasmid praxST with the indicated nucleotide substitutions in the PIP-1 or PIP-2 elements. Strains were grown in peptone-sucrose broth (PSB) and XOM2 media for $8 \mathrm{~h}$. Gene expression was analyzed by quantitative reverse-transcription PCR and normalized to expression from the ampC2 (PXO_RS14730) reference gene. Bars depict average expression level \pm standard deviation of three technical replicates. Similar results were observed in three independent experiments. 
$h r c U$ (HrpC operon) promoter (Tsuge et al. 2005). PIP box halfsites from several other HrpX-dependent control regions have similar mismatches from the consensus (Furutani et al. 2006; Koebnik et al. 2006; Song and Yang 2010; Tsuge et al. 2014; Wang et al. 2008; Yamazaki et al. 2008).

Similarly, the -10 sequences for both the $\operatorname{raxST}$ and the $\operatorname{raxX}$ promoters do not conform exactly to the consensus (Fig. 5). Nevertheless, a pair of substitutions at positions 2 and 6 eliminated $\operatorname{raxX}$ promoter activity (Fig. 6A) (the individual substitutions were not tested). Together, the mutational analyses reported here establish the sequences indicated in Figure $1 \mathrm{~B}$ as the HrpX-dependent promoters for $\operatorname{raxST}$ and $\operatorname{raxX}$ gene expression.

The divergent $\operatorname{raxST}$ and $\operatorname{raxX}$ PIP box sequences are separated by $88 \mathrm{nt}$ (Fig. 1B). Three other pairs of divergent PIP box sequences in $X$. oryzae pv. oryzae strain $\mathrm{PXO} 99^{\mathrm{A}}$ are separated by $14 \mathrm{nt}(h r c U-h r p B 1), 67 \mathrm{nt}($ hrcB-hpa2), and $171 \mathrm{nt}$ (PXO_RS17455-PXO_RS17465). Therefore, the relatively large

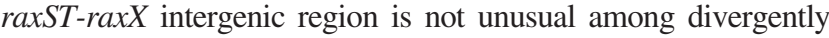
expressed HrpX-dependent genes. It is plausible that this intergenic region contains additional transcription factor regulatory sites (Mejía-Almonte et al. 2020).

$X$. oryzae pv. oryzae strain $\mathrm{PXO} 99^{\mathrm{A}}$ encodes a second T1SS, PctAB, that can partially substitute for RaxAB to secrete the RaxX peptide (Luu et al. 2019). Neither $\operatorname{raxC}$ (tolC) nor $p c t B$ gene expression was influenced by culture medium (Fig. 2C and D), consistent with the RNA-seq data of Zheng et al. (2021). Therefore, we conclude that HrpX regulates expression of only one T1SS in $X$. oryzae pv. oryzae $\mathrm{PXO} 99^{\mathrm{A}}$, RaxAB.

Annotations for the $X$. oryzae pv. oryzae strain $\mathrm{PXO} 99^{\mathrm{A}}$ genome sequence (Salzberg et al. 2008) have been refined and modified (Booher et al. 2015; Haft et al. 2018; Lei et al. 2013). Many of the originally annotated coding sequences were removed, including locus tag PXO_04481 in the raxST-raxX intergenic region (Fig. 1A). Recently, Xu et al. (2018) hypothesized that the protein putatively encoded by PXO_04481 regulates $\operatorname{rax} X$ gene expression. This analysis is based, in part, on comparing levels of $\beta$-glucuronidase reporter enzyme expression in strains carrying wild-type or mutant versions of the PXO_04481 sequence, all cultured overnight in PSB medium. The PXO_04481 mutant version displays, at most, a fourfold difference in reporter expression compared with the wild-type (Xu et al. 2018). In contrast, our experiments revealed a 35-fold or greater $\operatorname{raxX}$ induction when comparing expression from PSB-grown and XOM2-grown cultures (Figs. 2, 3, 4, and 6A). Moreover, the deduced PXO_04481 amino acid sequence is not conserved but, rather, displays different frameshifts in sequences from other Xanthomonas spp. (Supplementary Fig. S4). For these and other reasons, we believe that the physiologically relevant HrpX-dependent control mechanism best explains $\operatorname{raxX}$ and $\operatorname{rax} S T$ gene regulation.

Results reported in this article expand our knowledge of the HrpX pathogenicity regulon to include a T1SS-secreted sulfopeptide whose binding to plant cell surface receptors is distinct from T3SS-secreted effectors that interact with plant intracellular components. These results reinforce prior findings with T2SSsecreted substrates (Furutani et al. 2004; Wang et al. 2008; Yamazaki et al. 2008), that HrpX controls virulence factor synthesis beyond the T3SS and its effectors.

\section{MATERIALS AND METHODS}

\section{Bacterial cultures.}

PSB consisted of $1 \%$ peptone, $1 \%$ sucrose, and $0.1 \%$ sodium L(+)-glutamate. XOM2 medium (Tsuge et al. 2002) consisted of $0.18 \%$ xylose, $0.67 \mathrm{mM}$ L-methionine, $10 \mathrm{mM}$ sodium $\mathrm{L}(+)$-glutamate, $14.7 \mathrm{mM} \mathrm{KH} \mathrm{PO}_{4}, 0.04 \mathrm{mM} \mathrm{MnSO}$, and $5 \mathrm{mM}$ $\mathrm{MgCl}_{2}, \mathrm{pH}$ 6.5. Confluent $X$. oryzae pv. oryzae cultures were grown on PSB agar, harvested, and resuspended to a density of $10^{7} \mathrm{CFU} / \mathrm{ml}$ in either PSB or XOM2 medium, incubated with aeration to a density of approximately $10^{8} \mathrm{CFU} / \mathrm{ml}$, and harvested, all as described previously (Kim et al. 2019).

\section{$X$. oryzae pv. oryzae genetics and gene expression.}

$X$. oryzae pv. oryzae strain PXO99 ${ }^{\mathrm{A}}$ strains are listed in Table 1. The $X$. oryzae pv. oryzae $h r p X$ null mutant was constructed by insertional inactivation, as described previously (Kim et al. 2019). Briefly, the conditional-replication integration vector pJP5603 (Table 2) was used to clone an internal hrpX gene fragment (PCR primer sequences are in Table 3). Candidate strains were validated through PCR analysis.

Plasmids listed in Table 2 were constructed with standard recombinant DNA techniques using the PCR primers listed in Table 3. All plasmids were verified by sequencing and transformed into the appropriate $X$. oryzae pv. oryzae strain. Transformants were verified by PCR amplifying and sequencing the cloned insert, as described previously (Kim et al. 2019).

For complementation, the complete $h r p X$ coding sequence together with the upstream 582 nt was cloned into plasmid pVSP61. For measuring $\operatorname{raxX}$ and $\operatorname{raxST}$ gene expression, the $\operatorname{rax} X$ and $\operatorname{raxST}$ sequences from their indicated upstream regions through their termination codons were cloned into plasmid pPROBE-AT (Table 2). The resulting $\operatorname{rax}^{+}$and $\operatorname{raxST}^{+}$constructs were used to introduce site-specific substitutions in the

Table 1. Xanthomonas oryzae pv. oryzae PXO99 strains

\begin{tabular}{|c|c|c|}
\hline Strain & Note $^{a}$ & Reference \\
\hline PXO99 ${ }^{\mathrm{a}}$ & Philippine race 6 & Hopkins et al. 1992 \\
\hline$\triangle \operatorname{rax} X$ & $\operatorname{rax} X$ marker-free deletion & Pruitt et al. 2015 \\
\hline$\triangle \operatorname{raxST}$ & $\operatorname{rax} S T$ marker-free deletion & Pruitt et al. 2015 \\
\hline$h r p X:: \Omega$ & hrpX pJP5603 insertion, $\mathrm{Sm}^{\mathrm{R}}$ & This study \\
\hline$h r p X:: \Omega(\mathrm{p} h r p X)$ & hrpX::pJP5603 with phrpX, $\mathrm{Sm}^{\mathrm{R}}, \mathrm{Km}^{\mathrm{R}}$ & This study \\
\hline$\triangle \operatorname{rax} S T(\operatorname{prax} S T)$ & $\triangle \operatorname{rax} S T$ with $\operatorname{prax} S T, \mathrm{Ap}^{\mathrm{R}}$ & This study \\
\hline$\triangle \operatorname{rax} S T(\mathrm{prax} S T$ PIP-1) & $\triangle \operatorname{raxST}$ with praxST PIP-1 change, $\mathrm{Ap}^{\mathrm{R}}$ & This study \\
\hline$\triangle \operatorname{rax} S T$ (praxST PIP-2) & $\triangle \operatorname{rax} S T$ with praxST PIP-2 change, $\mathrm{Ap}^{\mathrm{R}}$ & This study \\
\hline$\triangle \operatorname{rax} X(\operatorname{prax} X \Delta 243)$ & $\triangle \operatorname{rax} X$ with $\operatorname{prax} X \Delta 243, \mathrm{Ap}^{\mathrm{R}}$ & This study \\
\hline$\triangle \operatorname{rax} X(\mathrm{p} \operatorname{rax} X \Delta 160)$ & $\triangle \operatorname{rax} X$ with $\operatorname{prax} X \Delta 160, \mathrm{Ap}^{\mathrm{R}}$ & This study \\
\hline$\triangle \operatorname{rax} X(\operatorname{prax} X \Delta 60)$ & $\triangle \operatorname{rax} X$ with $\operatorname{prax} X \Delta 60, \mathrm{Ap}^{\mathrm{R}}$ & This study \\
\hline$\triangle \operatorname{rax} X(\operatorname{prax} X \Delta+42)$ & $\triangle \operatorname{rax} X$ with $\operatorname{prax} X \Delta+42, \mathrm{Ap}^{\mathrm{R}}$ & This study \\
\hline$\triangle \operatorname{rax} X(\operatorname{prax} X \Delta 160-10)$ & $\triangle \operatorname{rax} X$ with $\operatorname{prax} X \Delta 243-10$ changes, $\mathrm{Ap}^{\mathrm{R}}$ & This study \\
\hline$\triangle \operatorname{rax} X(\mathrm{p} \operatorname{rax} X \Delta 160$ PIP-1) & $\triangle \operatorname{rax} X$ with praxX $\Delta 243$ PIP-1 change, Ap $^{\mathrm{R}}$ & This study \\
\hline$\triangle \operatorname{rax} X(\mathrm{p} \operatorname{rax} X \Delta 160$ PIP-2) & $\triangle \operatorname{rax} X$ with praxX $\Delta 243$ PIP-1 change, $A^{R}$ & This study \\
\hline
\end{tabular}

\footnotetext{
${ }^{\mathrm{a}} \mathrm{Sm}^{\mathrm{R}}, \mathrm{Km}^{\mathrm{R}}$, and $\mathrm{Ap}^{\mathrm{R}}$ indicate resistant to streptomycin, kanamycin, and ampicillin, respectively. PIP = plant-inducible promoter.
} 
control region sequences. For analyses, $\operatorname{rax} X$ and $\operatorname{raxST}$ plasmids were transformed into $\Delta \operatorname{raxX}$ and $\Delta \operatorname{raxST}$ null mutants, respectively.

qRT-PCR analysis was used to measure differential gene expression, as described previously (Kim et al. 2019). Briefly, RNA was extracted from $X$. oryzae pv. oryzae strains cultured in PSB or XOM2 and converted to cDNA, which was quantified by amplification with primer pairs listed in Table 3 .
Expression was normalized to ampC2 (PXO_RS14730) gene expression levels.

\section{$X$. oryzae pv. oryzae virulence assay.}

Oryza sativa subsp. japonica 'Taipei309' (TP309), and a transgenic line of TP309 carrying the Xa21 gene expressed from its native promoter (XA21-TP309), were used for rice inoculations. Rice plants were grown under standard greenhouse

Table 2. Plasmids

\begin{tabular}{|c|c|c|}
\hline Plasmid & Note $^{a}$ & Reference \\
\hline pJP5603 & Conditional replication vector pJP5603 with substituted antibiotic resistance from $\mathrm{Km}^{\mathrm{R}}$ to $\mathrm{Sm}^{\mathrm{R}}$ & Pruitt et al. 2015 \\
\hline pVSP61 & Broad-host-range vector used for complementation, $\mathrm{Km}^{\mathrm{R}}$ & Loper and Lindow 1994 \\
\hline pPROBE-AT & Broad-host-range promoter probe vector, $\mathrm{Ap}^{\mathrm{R}}$ & Miller et al. 2000 \\
\hline pJP5603 'hrpX' & pJP5603 derivative for single cross-over insertion of $h r p X$ (PXO RS18050), $\mathrm{Sm}^{\mathrm{R}}$ & This study \\
\hline $\mathrm{phrpX}$ & pVSP61 derivative, contains $h r p X$ from upstream 582 bp to stop codon, $\mathrm{Km}^{\mathrm{R}}$ & This study \\
\hline $\operatorname{prax} S T$ & pPROBE-AT derivative, contains $\operatorname{raxST}$ from $430 \mathrm{bp}$ upstream of GTG to stop codon, $\mathrm{Ap}^{\mathrm{R}}$ & This study \\
\hline praxST PIP-1 & praxST derivative, contains PIP-1 substitution (TTCGC $\rightarrow$ TTaGC), $\mathrm{Ap}^{\mathrm{R}}$ & This study \\
\hline praxST PIP-2 & praxST derivative, contains PIP-2 substitution $(\mathrm{TGCGC} \rightarrow \mathrm{TGaGC}), \mathrm{Ap}^{\mathrm{R}}$ & This study \\
\hline $\operatorname{praxX} \Delta 243$ & pPROBE-AT derivative, contains $\operatorname{rax} X$ from $391 \mathrm{bp}$ upstream of ATG to stop codon, $\mathrm{Ap}^{\mathrm{R}}$ & This study \\
\hline $\operatorname{prax} X \Delta 160$ & pPROBE-AT derivative, contains $\operatorname{raxX}$ from $308 \mathrm{bp}$ upstream of ATG to stop codon, Ap ${ }^{\mathrm{R}}$ & This study \\
\hline $\operatorname{praxX} \Delta 60$ & pPROBE-AT derivative, contains $\operatorname{rax} X$ from 205 bp upstream of ATG to stop codon, $\mathrm{Ap}^{\mathrm{R}}$ & This study \\
\hline praxX $\Delta+42$ & pPROBE-AT derivative, contains $\operatorname{rax} X$ from 106 bp upstream of ATG to stop codon, Ap $\mathrm{R}^{\mathrm{R}}$ & This study \\
\hline $\operatorname{prax} X \Delta 160-10$ & praxX $\Delta 160$ derivative, contains -10 substitutions $\left(\right.$ CAGGCT $\rightarrow$ CcGGCg), $\mathrm{Ap}^{\mathrm{R}}$ & This study \\
\hline $\operatorname{praxX} \Delta 160$ PIP-1 & praxX $\Delta 160$ derivative, contains PIP-1 substitution (TTCGT $\rightarrow$ TTaGT), Ap ${ }^{\mathrm{R}}$ & This study \\
\hline praxX $\Delta 160$ PIP-2 & praxX $\Delta 160$ derivative, contains PIP-2 substitution (GTCGT $\rightarrow$ GTaGT), Ap ${ }^{R}$ & This study \\
\hline
\end{tabular}

${ }^{a} \mathrm{Km}^{\mathrm{R}}, \mathrm{Sm}^{\mathrm{R}}$, and $\mathrm{Ap}^{\mathrm{R}}$ indicate resistant to kanamycin, streptomycin, and ampicillin, respectively. PIP = plant-inducible promoter.

Table 3. DNA oligonucleotide primers

\begin{tabular}{|c|c|}
\hline Primer name $^{a}$ & Sequence $\left(5^{\prime} \rightarrow 3^{\prime}\right)$ \\
\hline \multicolumn{2}{|c|}{ hrpX:: $\Omega$ pJP5603 insertion null allele } \\
\hline$\triangle \mathrm{hrpX}$-BamHI-F & GAGGGATCCCTGCAACACCTTCAACAGCGAC \\
\hline$\triangle \mathrm{hrpX}-E c o$ RI-R & GACGAATTCGTTCCACCTGTGCGTCCTGAC \\
\hline \multicolumn{2}{|l|}{ Complementation } \\
\hline hrpX-EcoRI-F & CACCGAATTCTTACATAACGGGCATGTGG \\
\hline hrpX-HindIII-R & GAGAAGCTTACCGTTGCAAGGTTTCCATCG \\
\hline raxST-HindIII-F & CAGAAGCTTCTGACGTCCTCGCAGGTTG \\
\hline $\operatorname{raxST-EcoRI-R~}$ & CAGGAATTCATACCAGCAGCGCTCCATG \\
\hline raxX391-HindIII-F & CACCAAGCTTGCCGGCGGGACGCATCGCCAGCCAAGC \\
\hline raxX308-HindIII-F & CACCAAGCTTGAATGCCGGCGATCCGGCTG \\
\hline $\operatorname{raxX} 205-H i n d I I I-F$ & CACCAAGCTTCACACACCGTCGTGCGCC \\
\hline raxX106-HindIII-F & CACCAAGCTTCTCATCGGCCACCCGCCAC \\
\hline $\operatorname{raxX}-E c o \mathrm{RI}-\mathrm{R}$ & CCCAGAATTCTCAATGGTGCCCGGGGTTGCGC \\
\hline \multicolumn{2}{|c|}{ Site-specific mutagenesis } \\
\hline raxST-PIP1-F & GATCGCCGGCATTaGCAAAGCGCAGCGCTTTTGCGCAGCGTGTCCGCG \\
\hline raxST-PIP1-R & CGCGGACACGCTGCGCAAAAGCGCTGCGCTTTGCtAATGCCGGCGATC \\
\hline raxST-PIP2-F & GATCGCCGGCATTCGCAAAGCGCAGCGCTTTTGaGCAGCGTGTCCGCG \\
\hline raxST-PIP2-R & CGCGGACACGCTGCtCAAAAGCGCTGCGCTTTGCGAATGCCGGCGATC \\
\hline $\operatorname{raxX}-\mathrm{PIP} 1-\mathrm{F}$ & GTCGCAAAGGCAGCCGCGCcGGCgGGAGCCCATGGTCCTGCCAC \\
\hline raxX-PIP1-R & GTGGCAGGACCATGGGCTCCcGCCgGCGCGGCTGCCTTTGCGAC \\
\hline raxX-PIP2-F & GACCTGGCGGATGCGACGTTaGTTCCCGCGCACACACCGTCGTGCGCC \\
\hline $\operatorname{raxX}-\mathrm{PIP} 2-\mathrm{R}$ & GGCGCACGACGGTGTGTGCGCGGGAACtAACGTCGCATCCGCCAGGTC \\
\hline $\operatorname{raxX}-10-\mathrm{F}$ & GTTCCCGCGCACACACCGTaGTGCGCCGGCCTGGGGTCGCAAAGGCAG \\
\hline $\operatorname{raxX}-10-\mathrm{R}$ & CTGCCTTTGCGACCCCAGGCCGGCGCACtACGGTGTGTGCGCGGGAAC \\
\hline \multicolumn{2}{|c|}{$\operatorname{rax} X$-specific primers for $5^{\prime}$-RACE } \\
\hline $\operatorname{raxX} \mathrm{SP} 1$ & GCGGATCGTGCTTGGGATTC \\
\hline $\operatorname{raxX} \mathrm{SP} 2$ & GACATGCTTCCACAGACGCTG \\
\hline \multicolumn{2}{|l|}{ qRT-PCR } \\
\hline $\operatorname{rax} X-q F$ & CAGCGTCTGTGGAAGCATGT \\
\hline $\operatorname{rax} X-q R$ & GCGGATCGTGCTTGGGATTC \\
\hline raxST-qF & CCTCCAACGTGCAGATCGAC \\
\hline raxST-qR & TATCGACGATCCAACCAAC \\
\hline $\operatorname{raxC}-\mathrm{qF}$ & TGAATCGGGAAGGTCAGGTA \\
\hline $\operatorname{raxC}-\mathrm{qR}$ & TGGTCTGGCTACCCTGAATC \\
\hline pctB-qF & GACGCATCTGTTGGAATCGC \\
\hline pctB-qR & AACTGGCTGGCCGTATTGAA \\
\hline $\mathrm{ampC} 2-\mathrm{qF}$ & GACTCGTAATGCCTACGACC \\
\hline ampC2-qR & AATTGCTCGTAGAAGCTGCC \\
\hline
\end{tabular}

${ }^{\mathrm{a}} \mathrm{RACE}=$ rapid amplification of cDNA ends and qRT-PCR $=$ quantitative reverse-transcription PCR. 
conditions, as described previously (Pruitt et al. 2015). Confluent $X$. oryzae pv. oryzae cultures were grown on PSB agar, harvested, and resuspended to a density of $10^{8} \mathrm{CFU} / \mathrm{ml}$ in water. Plant leaves were inoculated by the scissors clipping method, and water-soaked lesions were measured 14 days after inoculation, all as described previously (Kim et al. 2019).

\section{RNA isolation.}

qRT-PCR analysis was used to measure differential gene expression, as described previously (Kim et al. 2019). Briefly, RNA was extracted from $X$. oryzae pv. oryzae cell pellets by using the TRIzol MaxT bacterial RNA isolation kit (Invitrogen). For isolating $X$. oryzae pv. oryzae RNA from infected rice, plant leaves were inoculated as described above $(X$. oryzae pv. oryzae virulence assay). Fresh leaf tissue $(2 \mathrm{~cm})$ from the end of watersoaked lesions was collected at 8 or 12 days after inoculation. Frozen leaf tissue was ground to fine powder and $X$. oryzae pv. oryzae RNA was extracted using TRIzol (Invitrogen). RNA samples were treated with TURBO DNAse (Ambion), followed by cDNA synthesis using MultiScribe Reverse transcription (Invitrogen). For quantitative PCR, cDNAs were analyzed by amplification with the SsoFast EvaGreen Supermix (Bio-Rad), using the primer pairs listed in Table 2. Expression was normalized to ampC2 (PXO_RS14730) gene expression levels.

\section{$\operatorname{rax} X$ transcription initiation site.}

The 5'-RACE method was used to determine $5^{\prime}$ ends of $\operatorname{raxX}$ mRNA species (Schaefer 1995). Cultures were grown in XOM2 medium and total RNA was prepared as described above. Analysis used the 5'/3' RACE kit (Roche, Basel, Switzerland) following the manufacturer's instructions. First-strand cDNA was synthesized using the $\operatorname{raxX}$ gene-specific primer SP1 (Table 3), during which the transcript was degraded by the reversetranscription Rnase $\mathrm{H}$ activity. The first-strand cDNA was purified by using Wizard DNA Clean-Up System (Promega Corp., Madison, WI, U.S.A.), and a homopolymeric A-tail was added to $3^{\prime}$ end by using terminal transferase and dATP. The dA-tailed cDNA was PCR amplified with the dT-Anchor primer and a the $\operatorname{raxX}$ gene-specific primer SP2 (Table 3). The amplified DNA was cloned in plasmid pGEM-T Easy (Promega Corp.) and sequenced to determine $\operatorname{rax} X$ transcript $5^{\prime}$ ends.

\section{Genome sequence analysis.}

Zheng et al. (2021) used RNA-seq to identify differentially expressed genes from $X$. oryzae pv. oryzae strain PXO99 ${ }^{\mathrm{A}}$ cultured in XOM2 medium. They compared the wild type and 10 different regulatory gene null mutant strains. We extracted approximately 160 differentially expressed genes in the comparison between $h r p X^{+}$and $\Delta h r p X$ strains. Approximately 40 of these genes, many encoding components required for flagellaror type IV pilus-dependent motility, are expressed at a higher level in the $\Delta h r p X$ strain and, presumably, are controlled by HrpX-dependent repression. We did not characterize these genes further.

The remaining approximately 120 genes are expressed at a lower level in the $\Delta h r p X$ strain and, therefore, likely are controlled by HrpX-dependent transcription activation. Many of these genes, particularly the hrp genes themselves, are in apparent operons, leaving roughly 80 upstream control region sequences to examine for PIP box sequences. We used SeqBuilder (DNAStar, Madison, WI, U.S.A.) to scan these control regions visually for potential PIP box promoter sequences, using the $X$. oryzae pv. oryzae PXO99 ${ }^{\mathrm{A}}$ genome sequence (accession NC_010717.2). We confined our selection of potential PIP box promoter sequences to those with the standard 15-nt spacing between elements (Supplementary Fig. S2); thus, we potentially overlooked any that have different spacing, as suggested previously for the $h r p F$
(Huguet and Bonas 1997) and cysP2 (Furutani et al. 2004) promoters.

\section{LITERATURE CITED}

Bogdanove, A. J., Beer, S. V., Bonas, U., Boucher, C. A., Collmer, A. Coplin, D. L., Cornelis, G. R., Huang, H. C., Hutcheson, S. W., Panopoulos, N. J., and Van Gijsegem, F. 1996. Unified nomenclature for broadly conserved hrp genes of phytopathogenic bacteria. Mol. Microbiol. 20:681-683.

Booher, N. J., Carpenter, S. C. D., Sebra, R. P., Wang, L., Salzberg, S. L., Leach, J. E., and Bogdanove, A. J. 2015. Single molecule realtime sequencing of Xanthomonas oryzae genomes reveals a dynamic structure and complex TAL (transcription activator-like) effector gene relationships. Microb. Genomics 1:e000032.

Busby, S., and Ebright, R. H. 1994. Promoter structure, promoter recognition, and transcription activation in prokaryotes. Cell 79:743-746.

Büttner, D. 2016. Behind the lines-actions of bacterial type III effector proteins in plant cells. FEMS Microbiol. Rev. 40:894-937.

Büttner, D., and Bonas, U. 2010. Regulation and secretion of Xanthomonas virulence factors. FEMS Microbiol. Rev. 34:107-133.

Buvinger, W. E., and Riley, M. 1985. Nucleotide sequence of Klebsiella pneumoniae lac genes. J. Bacteriol. 163:850-857.

Crooks, G. E., Hon, G., Chandonia, J. M., and Brenner, S. E. 2004 WebLogo: A sequence logo generator. Genome Res. 14:1188-1190.

Cunnac, S., Boucher, C., and Genin, S. 2004. Characterization of the cisacting regulatory element controlling HrpB-mediated activation of the type III secretion system and effector genes in Ralstonia solanacearum. J. Bacteriol. 186:2309-2318.

da Silva, F. G., Shen, Y., Dardick, C., Burdman, S., Yadav, R. C., de Leon, A. L., and Ronald, P. C. 2004. Bacterial genes involved in type I secretion and sulfation are required to elicit the rice Xa21-mediated innate immune response. Mol. Plant-Microbe Interact. 17:593-601.

Fenselau, S., and Bonas, U. 1995. Sequence and expression analysis of the hrpB pathogenicity operon of Xanthomonas campestris pv. vesicatoria which encodes eight proteins with similarity to components of the Hrp, Ysc, Spa, and Fli secretion systems. Mol. Plant-Microbe Interact. 8: 845-854.

Furutani, A., Nakayama, T., Ochiai, H., Kaku, H., Kubo, Y., and Tsuge, S. 2006. Identification of novel HrpXo regulons preceded by two cisacting elements, a plant-inducible promoter box and a -10 box-like sequence, from the genome database of Xanthomonas oryzae pv. oryzae. FEMS Microbiol. Lett. 259:133-141.

Furutani, A., Tsuge, S., Ohnishi, K., Hikichi, Y., Oku, T., Tsuno, K., Inoue, Y., Ochiai, H., Kaku, H., and Kubo, Y. 2004. Evidence for HrpXodependent expression of type II secretory proteins in Xanthomonas oryzae pv. oryzae. J. Bacteriol. 186:1374-1380.

Haft, D. H., DiCuccio, M., Badretdin, A., Brover, V., Chetvernin, V., O’Neill, K., Li, W., Chitsaz, F., Derbyshire, M. K., Gonzales, N. R., Gwadz, M., Lu, F., Marchler, G. H., Song, J. S., Thanki, N., Yamashita, R. A., Zheng, C., Thibaud-Nissen, F., Geer, L. Y., MarchlerBauer, A., and Pruitt, K. D. 2018. RefSeq: An update on prokaryotic genome annotation and curation. Nucleic Acids Res. 46:D851-D860.

Han, S. W., Lee, S. W., Bahar, O., Schwessinger, B., Robinson, M. R., Shaw, J. B., Madsen, J. A., Brodbelt, J. S., and Ronald, P. C. 2012 Tyrosine sulfation in a Gram-negative bacterium. Nat. Commun. 3: 1153

Hopkins, C. M., White, F. F., Choi, S. H., Guo, A., and Leach, J. E. 1992. Identification of a family of avirulence genes from Xanthomonas oryzae pv. oryzae. Mol. Plant-Microbe Interact. 5:451-459.

Huguet, E., and Bonas, U. 1997. hrpf of Xanthomonas campestris pv. vesicatoria encodes an $87-\mathrm{kDa}$ protein with homology to NoIX of Rhizobium fredii. Mol. Plant-Microbe Interact. 10:488-498.

Kamdar, H. V., Kamoun, S., and Kado, C. I. 1993. Restoration of pathogenicity of avirulent Xanthomonas oryzae pv. oryzae and X. campestris pathovars by reciprocal complementation with the hrpXo and $h r p X c$ genes and identification of HrpX function by sequence analyses. J. Bacteriol. 175:2017-2025.

Kim, H., Joe, A., Lee, M., Yang, S., Ma, X., Ronald, P. C., and Lee, I. 2019. A genome-scale co-functional network of Xanthomonas genes can accurately reconstruct regulatory circuits controlled by twocomponent signaling systems. Mol. Cells 42:166-174.

Koebnik, R., Krüger, A., Thieme, F., Urban, A., and Bonas, U. 2006. Specific binding of the Xanthomonas campestris pv. vesicatoria AraC-type transcriptional activator $\mathrm{HrpX}$ to plant-inducible promoter boxes. J. Bacteriol. 188:7652-7660. 
Lee, D. J., Minchin, S. D., and Busby, S. J. W. 2012. Activating transcription in bacteria. Annu. Rev. Microbiol. 66:125-152.

Lei, Y., Kang, S. K., Gao, J., Jia, X. S., and Chen, L. L. 2013. Improved annotation of a plant pathogen genome Xanthomonas oryzae pv. oryzae PXO99A. J. Biomol. Struct. Dyn. 31:342-350.

Leonard, S., Hommais, F., Nasser, W., and Reverchon, S. 2017. Plantphytopathogen interactions: Bacterial responses to environmental and plant stimuli. Environ. Microbiol. 19:1689-1716.

Lindgren, P. B. 1997. The role of hrp genes during plant-bacterial interactions. Annu. Rev. Phytopathol. 35:129-152.

Liu, F., McDonald, M., Schwessinger, B., Joe, A., Pruitt, R., Erickson, T., Zhao, X., Stewart, V., and Ronald, P. C. 2019. Variation and inheritance of the Xanthomonas raxX-raxSTAB gene cluster required for activation of XA21-mediated immunity. Mol. Plant Pathol. 20:656-672.

Loper, J. E., and Lindow, S. E. 1994. A biological sensor for iron available to bacteria in their habitats on plant surfaces. Appl. Environ. Microbiol. 60:1934-1941.

Luu, D. D., Joe, A., Chen, Y., Parys, K., Bahar, O., Pruitt, R., Chan, L. J. G., Petzold, C. J., Long, K., Adamchak, C., Stewart, V., Belkhadir, Y., and Ronald, P. C. 2019. Biosynthesis and secretion of the microbial sulfated peptide RaxX and binding to the rice XA21 immune receptor. Proc. Natl. Acad. Sci. U.S.A. 116:8525-8534.

Mejía-Almonte, C., Busby, S. J. W., Wade, J. T., van Helden, J., Arkin, A. P., Stormo, G. D., Eilbeck, K., Palsson, B. O., Galagan, J. E., and Collado-Vides, J. 2020. Redefining fundamental concepts of transcription initiation in bacteria. Nat. Rev. Genet. 21:699-714.

Miller, W. G., Leveau, J. H., and Lindow, S. E. 2000. Improved gfp and inaZ broad-host-range promoter-probe vectors. Mol. Plant-Microbe Interact. 13:1243-1250

Mukaihara, T., Tamura, N., Murata, Y., and Iwabuchi, M. 2004. Genetic screening of Hrp type III-related pathogenicity genes controlled by the HrpB transcriptional activator in Ralstonia solanacearum. Mol. Microbiol. 54:863-875.

Niño-Liu, D. O., Ronald, P. C., and Bogdanove, A. J. 2006. Xanthomonas oryzae pathovars: Model pathogens of a model crop. Mol. Plant Pathol. 7:303-324.

Noël, L., Thieme, F., Nennstiel, D., and Bonas, U. 2002. Two novel type III-secreted proteins of Xanthomonas campestris pv. vesicatoria are encoded within the hrp pathogenicity island. J. Bacteriol. 184:13401348.

Oku, T., Tanaka, K., Iwamoto, M., Inoue, Y., Ochiai, H., Kaku, H., Tsuge, S., and Tsuno, K. 2004. Structural conservation of hrp gene cluster in Xanthomonas oryzae pv. oryzae. J. Gen. Plant Pathol. 70: 159-167.

Pruitt, R. N., Joe, A., Zhang, W., Feng, W., Stewart, V., Schwessinger, B., Dinneny, J. R., and Ronald, P. C. 2017. A microbially derived tyrosine-sulfated peptide mimics a plant peptide hormone. New Phytol. 215:725-736

Pruitt, R. N., Schwessinger, B., Joe, A., Thomas, N., Liu, F., Albert, M., Robinson, M. R., Chan, L. J., Luu, D. D., Chen, H., Bahar, O., Daudi, A., De Vleesschauwer, D., Caddell, D., Zhang, W., Zhao, X., Li, X., Heazlewood, J. L., Ruan, D., Majumder, D., Chern, M., Kalbacher, H., Midha, S., Patil, P. B., Sonti, R. V., Petzold, C. J., Liu, C. C., Brodbelt, J. S., Felix, G., and Ronald, P. C. 2015. The rice immune receptor XA21 recognizes a tyrosine-sulfated protein from a Gram-negative bacterium. Sci. Adv. 1:e1500245.

Salzberg, S. L., Sommer, D. D., Schatz, M. C., Phillippy, A. M., Rabinowicz, P. D., Tsuge, S., Furutani, A., Ochiai, H., Delcher, A. L., Kelley, D., Madupu, R., Puiu, D., Radune, D., Shumway, M., Trapnell, C., Aparna, G., Jha, G., Pandey, A., Patil, P. B., Ishihara, H., Meyer, D. F., Szurek, B., Verdier, V., Koebnik, R., Dow, J. M., Ryan, R. P., Hirata, H., Tsuyumu, S., Won Lee, S., Seo, Y. S., Sriariyanum, M., Ronald, P. C., Sonti, R. V., Van Sluys, M. A., Leach, J. E., White, F. F., and Bogdanove, A. J. 2008. Genome sequence and rapid evolution of the rice pathogen Xanthomonas oryzae pv. oryzae PXO99A. BMC Genomics 9:204.

Schaefer, B. C. 1995. Revolutions in rapid amplification of cDNA ends: New strategies for polymerase chain reaction cloning of full-length cDNA ends. Anal. Biochem. 227:255-273.

Schneider, T. D., and Stephens, R. M. 1990. Sequence logos: A new way to display consensus sequences. Nucleic Acids Res. 18:6097-6100.

Schulte, R., and Bonas, U. 1992. Expression of the Xanthomonas campestris pv. vesicatoria hrp gene cluster, which determines pathogenicity and hypersensitivity on pepper and tomato, is plant inducible. J. Bacteriol. 174:815-823.

Shultzaberger, R. K., Chen, Z., Lewis, K. A., and Schneider, T. D. 2007. Anatomy of Escherichia coli sigma70 promoters. Nucleic Acids Res. 35:771-788.

Song, C., and Yang, B. 2010. Mutagenesis of 18 type III effectors reveals virulence function of $\mathrm{XopZ}_{\mathrm{PXO} 99}$ in Xanthomonas oryzae pv. oryzae. Mol. Plant-Microbe Interact. 23:893-902.

Song, W. Y., Wang, G. L., Chen, L. L., Kim, H. S., Pi, L. Y., Holsten, T., Gardner, J., Wang, B., Zhai, W. X., Zhu, L. H., Fauquet, C., and Ronald, P. 1995. A receptor kinase-like protein encoded by the rice disease resistance gene, $\mathrm{Xa21}$. Science 270:1804-1806.

Tampakaki, A. P., Skandalis, N., Gazi, A. D., Bastaki, M. N., Sarris, P. F., Charova, S. N., Kokkinidis, M., and Panopoulos, N. J. 2010 Playing the "Harp": Evolution of our understanding of hrp/hrc genes. Annu. Rev. Phytopathol. 48:347-370.

Teper, D., Pandey, S. S., and Wang, N. 2021. The HrpG/HrpX regulon of Xanthomonads-an insight to the complexity of regulation of virulence traits in phytopathogenic bacteria. Microorganisms 9:187.

Tsuge, S., Furutani, A., Fukunaka, R., Oku, T., Tsuno, K., Ochiai, H. Inoue, Y., Kaku, H., and Kubo, Y. 2002. Expression of Xanthomonas oryzae pv. oryzae hrp genes in XOM2, a novel synthetic medium. J. Gen. Plant Pathol. 68:363-371.

Tsuge, S., Furutani, A., and Ikawa, Y. 2014. Regulatory network of hrp gene expression in Xanthomonas oryzae pv. oryzae. J. Gen. Plant Pathol. 80:303-313.

Tsuge, S., Terashima, S., Furutani, A., Ochiai, H., Oku, T., Tsuno, K., Kaku, H., and Kubo, Y. 2005. Effects on promoter activity of base substitutions in the cis-acting regulatory element of HrpXo regulons in Xanthomonas oryzae pv. oryzae. J. Bacteriol. 187:2308-2314.

Wagner, S., Grin, I., Malmsheimer, S., Singh, N., Torres-Vargas, C. E., and Westerhausen, S. 2018. Bacterial type III secretion systems: A complex device for the delivery of bacterial effector proteins into eukaryotic host cells. FEMS Microbiol. Lett. 365:fny201.

Wang, F. F., and Qian, W. 2019. The roles of histidine kinases in sensing host plant and cell-cell communication signal in a phytopathogenic bacterium. Philos. Trans. R. Soc. Lond. B Biol. Sci. 374:20180311.

Wang, L., Rong, W., and He, C. 2008. Two Xanthomonas extracellular polygalacturonases, PghAxc and $\mathrm{PghBxc}$, are regulated by type III secretion regulators $\mathrm{HrpX}$ and $\mathrm{HrpG}$ and are required for virulence. Mol. Plant-Microbe Interact. 21:555-563.

Wengelnik, K., and Bonas, U. 1996. HrpXv, an AraC-type regulator, activates expression of five of the six loci in the hrp cluster of Xanthomonas campestris pv. vesicatoria. J. Bacteriol. 178:3462-3469.

White, F. F., Potnis, N., Jones, J. B., and Koebnik, R. 2009. The type III effectors of Xanthomonas. Mol. Plant Pathol. 10:749-766.

Xu, C., Wang, Y., Liu, S., Xie, Q., He, N., Shi, C., Niu, X., He, C., Li, C., and Tao, J. 2018. RaxM regulates the AvrXa21 (RaxX)-mediated immune response. Mol. Plant Pathol. 19:2363-2369.

Yamazaki, A., Hirata, H., and Tsuyumu, S. 2008. HrpG regulates type II secretory proteins in Xanthomonas axonopodis pv. citri. J. Gen. Plant Pathol. 74:138-150.

Zheng, D., Wang, H., Zhong, H., Ke, W., Hu, H., Sun, M., and Ruan, L. 2021. Elucidation of the pathogenicity-associated regulatory network in Xanthomonas oryzae pv. oryzae. mSystems 6:e0789-20. 